\title{
KEPRIBADIAN MUSLIM TERHADAP PERILAKU BULLYING DI RUMAH SAKIT ISLAM WILAYAH KOTA PALEMBANG
}

\author{
Budiman, Eko Oktapiya Hadinata, Adi Apriatna \\ Fakultas Psikologi UIN Raden Fatah Palembang \\ budiman_uin@radenfatah.ac.id \\ eko_oktapiya_hadinata@yahoo.com \\ adiapriatna7@gmail.com
}

\begin{abstract}
Purpose of the research to know the influence of Muslim Personality on Bullying Behaviours in Islamic Hospital of Palembang City Region. Some research that has been done in the West states that $56 \%$ of nurses become victims of bullying in their of workplacecausing harm to both individuals and organizations. The hypothesis of this research is that there is influence of Muslim personality on bullying behaviours in the workplace. The higher the comprehensionand practice of Muslim personality, the lower the occurrence of bullying behaviours in the workplace. This research using correlation research methods, research sample 214 nurses from 2 Islamic Hospital in Palembang, data collected using scalemethod, namely: Bullying Behaviour scale and Muslim Personality Scale and data analysis methods using simple regression analysis with SPSS programming. 22.5 for windows. Based on the results obtained $\mathrm{r}=0.412 \mathrm{in}$ other word, there is influence of Muslim personality on bullying behaviours in the workplace. The higher the understanding and practice of Muslim personality, the lower the occurrence of bullying behaviours in the workplace and $\mathrm{r}^{2}$ of 0.170 means that $17 \%$ of Muslim personality contributed to bullying behaviours in the workplace.
\end{abstract}

Keywords: Bullying Behavior, Muslim Personality

\begin{abstract}
ABSTRAK
Penelitian ini bertujuan untuk mengetahui Pengaruh Kepribadian Muslim terhadap Perilaku Bullying di Rumah Sakit Islam Wilayah Kota Palembang. Beberapa penelitian yang telah dilakukan di Barat manyatakan bahwa $56 \%$ perawat menjadi korban bullying di tempat mereka bekerja sehingga menyebab kerugian baik secara individu mapun secara organisasi.Hipotesis penelitian ini adalah ada pengaruh kepribadian muslim terhadap perilaku bullying di tempat kerja. Semakin tinggi pemahaman dan pengamalan keperibadian muslim maka semakin rendah terjadinya perilaku bullying di tempat kerja. Penelitian menggunakan metode penelitian korelasional, sampel penelitian 214 orang perawat dari 2 Rumah Sakit Islam di Palembang, metode pengumpulan data dengan menggunakan skala, yaitu : skala Prilaku Bullying dan Skala Kepribadian Muslim serta metode analisis data mennggunakan analisis regresi sederhana dengan bantunan program SPSS. 2.5 for windows. Berdasarkan hasil analisis diperoleh $r$ sebesar 0,412 artinya Ada pengaruh kepribadian muslim terhadap perilaku bullying di tempat kerja. Semakin tinggi pemahaman dan pengamalan keperibadian muslim maka semakin rendah terjadinya perilaku bullying di tempat kerja dan didapati $r^{2}$ sebesar 0,170 artinya sebesar $17 \%$ kepribadian muslim berkontribusi terhadap perilaku bullying di tempat kerja.
\end{abstract}

Kata Kunci: Perilaku Bullying, Kepribadian Muslim

\section{PENDAHULUAN}

Perubahan teknologi, sosiopolitik, persaingan dan ekonomi telah menyebabkan tekanan terhadap organisasi dalam menyesuaikan keadaan tersebut (Martino, V. Di, Hoel, H. \& Cooper, c. 2003).Untuk memenuhi tuntutan itu, organisasi akan memaksimalkan penggunaan sumber daya 
manusia yang ada untuk mencapai suatu tujuan sehingga tidak menimbulkan dampak psikologisseperti perlakuan bullying dalam diri pekerja suatu organisasi. (Sheehan, M. \& Griffiths, J. 2011).

Bullying di tempat kerja bukan saja dialami secara individu tetapi juga secara langsung memberikan dampak kepada organisasi. Antara dampak yang ditemukan terhadap individu yang menjadi korban perlakuanbullying tersebut dapat dilihat dari dua sudut, psikologi dan fisik (E. Sismani Papacosta and others, 2014, p. 311). Dampak psikologi adalah seperti depresi, stres, dan self esteem yang rendah, sedangkan dari sudut fisik seperti sakit perut, susah tidur dan sering mengalami keletihan yang kronik (Salin, D. Ways, 2003).

Bullying bukan saja memberi dampak jangka panjang kepada mental dan fisik korban tetapi juga memberikan implikasi terhadap keluarganya (Dye, Thomas R, 2005). Bagi organisasi, kerugian terjadi disebabkan oleh bullying seperti kehilangan produktivitas, tunover yang tinggi, dan juga biaya perawatan tinggi pada korban bullying. Selain itu, organisasi juga terpaksa menanggung kerugian disebabkan ganti rugi korban dan tuntutan ketidakmampuan dalam menjalankan tugas akibat menjadi korban bullying. Korban selalu dipersalahkan ketika terjadinya perilaku bullying di tempat kerja, hal ini disebabkan oleh sifat mereka yang lemah dalam menanggulangi konflik, malu dan memiliki kompetensi sosial yang rendah ( Einarsen, S., Raknes, B., Matthiesen, S. Bullying and Harassment, 1994).Namun begitu, terdapat juga sebaliknya korban bullying akan bersikap lebih jujur dan kreatif, juga memiliki kemampuan untuk mengendalikan pelaku bullying. Keadaan ini terjadi karena pengalaman di bullying adalah satu perubahan proses kognitif seseorang disebabkan oleh kesinambungan antara faktor lingkungan dan juga kepribadian (Davenport, N., Distler Schwartz, R., Elliot, G., 2001).

Pengaruh perilaku bullying dilihat penting karena dapat memberikan dampak yang serius kepada korban. Perilaku bullying bukan hanya dilihat dari sudut dampaknya saja tetapi juga perlu dilihat dari sudut faktor yang menyebabkan perilaku itu terjadi. Kegagalan memahami penyebab perilaku tersebut terjadi akan menyebabkan kesulitan dalam usaha mengatasi perilaku itu sendiri. Kondisi ini terjadi disebabkan oleh perilaku bullying itu sendiri yang dilihat sangat kompleks karena terdapat pelbagai faktor yang menyebabkan perilaku itu terjadi di tempat kerja. Keadaan ini sekiranya dibiarkan terus menerus akan menyebabkan organisasi terpaksa mengeluarkan biaya yang besar untuk tujuan mencari pekerja baru.(Khalib, A.L. and Ngan, H.U, 2006).

Penelitian mengenai perilaku bullying telah muncul di United Kingdom pada tahun 1990, seorang wartawan bernama Adrea telah membawa isu ini kepada perhatian umum di Inggris melalui siaran radio di BBC (British Broadcasting Corporation) dan melabelkan fenomena mobbing tersebut sebagai bullying. Perkembangan ini diikuti oleh beberapa penelitian internasional berskala besar yang secara jelasnya menunjukkan keseriusan fenomena yang terjadi di tempat kerja. Pengaruh daripada upaya yang dilakukan oleh Adrea menyebabkan istilah bullying lebih banyak digunakan di United Kingdom (Hoel, H. \& Cooper, C.,200).

Di Amerika Serikat, fenomena bullying di tempat kerja telah diuraikan oleh Carrol Brodsky pada tahun 1990 melalui bukunya yang bertajuk The Harassed Worker pengaruh daripada trend yang terjadi di Inggris. Melalui penelitian yang dilakukan, Brodsky telah menguraikan pelbagai kasus yang menunjukkan semua tahapan organisasi menyatakan bahwa terjadinya penzaliman 
secara sistematis oleh atasan dan rekan sejawat di tempat kerja dengan pengaruh buruk terhadap produktivitas dan kesejahteraan mereka. Pada akhir 1990, penelitian berkenaan bullying di tempat kerja lebih memfokuskan kepada korban. Penelitian berkenaan bullying terus berkembang dengan secara cepat di Amerika Serikat pada tahun 2000 setelah usaha Gary dan Ruth Namie menerbitkan buku dan mewujudkan Workplace Bullying Institute (WBI) untuk membantu korban bullying. Di Taiwan Studi keperawatan klinis oleh Pai dan Lee, melaporkan angka tinggi insiden yang melibatkan intimidasi di tempat kerja. Penelitian yang dilakukan di RSUP M. Djamil Padang, menjelaskan bahwa sebanyak 42,2\% perawat mengalami bullying verbal (Dewi, S. P, 2013).

Faktor-faktor yang mempengaruhi perilaku bullying di tempat kerja dapat dilihat dari sudut organisasi dan juga individu. Namun begitu, fokus penelitian terdahulu lebih terarah terhadap faktor organisasi berbanding individu. Faktor-faktor organisasi seperti kepemimpinan, budaya organisasi, struktur kerja merupakan penyebab terjadinya bullying di tempat kerja. Namun begitu, faktor individu seperti kepribadian seorang atasan yang lebih menjurus kepada perlakuan bullying karena tidak memiliki kemampuan dan kecerdasan emosi yang baik untuk disesuaikan dengan iklim organisasi.

Aspek kepribadian memainkan peran penting terhadap terjadinya perilaku bullying di tempat kerja. Hal ini menunjukkan bahwa ciri kepribadian korban memberikan pengaruh terhadap perilaku bawahan di tempat kerja. Berdasarkan penelitian yang dilakukan oleh Einarsen, diperoleh ada pengaruh akibat perilaku bullying yang dilakukan oleh atasan lebih serius daripada bullying yang dilakukan oleh rekan kerja. Selain atasan memiliki jabatan dalam suatu organisasi, tindakan yang dilakukan oleh atasan terhadap bawahan secara negatif dan kasar dilihat sulit untuk dibendung disebabkan tindakan atasan akan dibenarkan oleh pihak organisasi sehingga meninggalkan pengaruh yang serius kepada korban bullying (Zapf, D., and Einarsen, S, 2001).

Oleh karena itu, setidak-tidaknya kepribadian jika dilihat dari sudut agama (baca: Islam) idealnya adalah, kepribadian muslim mampu merealisasikan kehendak Tuhan dan mampu mengoptimalkan pelbagai fungsi seperti, akal, hati dan nafs. Dengan demikian, dalam berpikir, berbicara, merespon dan berperilaku dalam kehidupan sehari-hari sesuai dengan isyarat al-Qur'an dan tentunya tidak keluar dari etika atau moral sebagaimana harusnya, kepribadian muslim.

Penelitian ini dilakukan di Rumah Sakit Islam Palembang, dan akan melihat fenomena bullying yang terjadi pada perawat yang bekerja di rumah sakit. Pemilihan rumah sakit sebagai tempat penelitian ini disebabkan ada beberapa penelitian terdahulu yang dilakukan pada tenaga medis di rumah sakit antara lain, penelitian yang dilakukan oleh Lyn Quin, Trinchero dan Teo. Kedua penelitian memberikan gambaran bahwa hampir $56 \%$ perawat menjadi korban bullying di tempat mereka bekerja. Berdasarkan uraian ini maka peneliti merasa perlu melakukan penelitian secara komprehensif mengenai Peranan Kepribadian Muslim Terhadap Perilaku Bullying pada Perawat Rumah Sakit Islam Palembang.

\section{METODE PENELITIAN}

\section{Jenis penelitian}

Setiap penelitian memiliki arah dan tujuan yang jelas. Penelitian yang baik adalah penelitian yang memiliki metode penelitian yang tepat. Dalam penelitian ini metode yang digunakan adalah korelasional. Penelitian korelasional adalah suatu penelitian yang bertujuan untuk mendeteksi sejauh mana 
variasi-variasi pada faktor berkaitan dengan variasi-variasi pada satu atau lebih faktor lain berdasarkan pada koefisien korelasi (Sumadi Suryabrata, 2009).

\section{Populasi dan Sampel}

Populasi adalah sejumlah individu yang mempunyai satu ciri atau sifat yang sama, yang selanjutnya dikenal generalisasi dari hasil penelitia (Kerlinger, F.N, 2004) Populasi pada penelitian ini adalah perawat Rumah Sakit Islam Wilayah kota Palembang.

Pada penelitian ini, peneliti menggunakan teknik profosive sampling yaitu teknik pengambilan sampel berdasarkan kriteria (Sutrisno Hadi, 2000). Adapun kriteria subjek yang akan dijadikan sampel dalam penelitian ini adalah

1. Berstatus Pegawai Tetap

2. Masa Kerja Minimal 2 Tahun

3. Pendidikan Minimal DIII Keperawatan

Berdasarkan kriteria yang telah ditetapkan, maka diperoleh jumlah sampel dalam penelitian ini adalah berjumlah 214 perawat (Rumah Sakit Muhammaiyah dan Ruma Sakit Islam Siti Khadijah).

\section{Metode Pengumpulan Data}

Data penelitian akan dikumpulkan melalui skala psikologi. Skala psikologi merupakan suatu metode penelitian dengan menggunakan daftar pernyataan yang di dalamnya terdapat aspek-aspek yang harus dijawab oleh subjek yang sedang diteliti.

\section{Skala Perilaku Bullying}

Skala Prilaku Bullying menggunakan suatu bentuk pengukuran berupa skala dari Likert yang diadaptasi dari Einrsent \& Hoel terdiri dari 20 item (Einarsen, S., Hoel, H., Notelaers, G, 2009)penyataan dan 5 alternatif jawaban dengan kisaran skor dari 1- 5 tiap item.
2. Skala Kepribadian Muslim

Skala Kepribadian Muslim dibuat berdasarkan pendapat yang dikemukakan oleh Imam al-Ghazali terdiri dari 20 item penyataan dengan 5 jawaban setiap itemnya (Faiza, Salahsiah,\& Sharifuddin, 2015).

\section{Metode Analisis Data}

Metode analisis data dalam penelitian ini terdiri dari 2 tahapan akan diuraikan sebagai berikut :

1. Validitas alat ukur adalah seberapa jauh kemampuan alat ukur dapat dengan jitu mengungkap apa yang hendak diukur (Hadi, 2000). Suatu alat ukur dikatakan valid apabila alat tersebut memberikan hasil pengukuran yang sesuai dengan maksud dan tujuan dari diadakannya pengukuran itu sendiri (Kerlinger, 2004).

2. Uji Hipotesis dilakukan mengetahui hubungan antara variabel bebas dengan variabel terikat dengan menggunakan uji analisis regresi sederhana.

\section{HASIL DAN PEMBAHASAN}

Hasil uji regresi penelitian tentang pengaruh kepribadian muslim terhadap perilaku bullying dengan nilai Sig. 0,000 yang berarti nilai Sig $<0,05$. Dengan demikian, secara statistik ada pengaruh perilaku bullying terhadap kepribadian muslim.

\begin{tabular}{rl|r|r|r|r|r}
\hline & Model & $\begin{array}{r}\text { Sum of } \\
\text { Squares }\end{array}$ & df & $\begin{array}{r}\text { Mean } \\
\text { Square }\end{array}$ & F & Sig. \\
\hline 1 & Regression & & & 2283,1 & 30, & \\
& & 2283,103 & 1 & 03 &, $000^{\mathrm{a}}$ \\
& & & & & \\
& & & \\
& Residual & 11159,73 & 148 & 75,404 & & \\
& & 0 & & & & \\
& Total & 13442,83 & 149 & & & \\
& & 3 & & & & \\
\hline
\end{tabular}

Hal ini senada dengan Einarsen bahwa, pelaku dan korban melaporkan yang Kepribadian dan cara korban di tempat kerja memainkan peran penting menyebabkan 
bullying terjadi (Einarsen, S, 1994). Walaupun pengalaman korban terhadap perilaku bullying adalah berdasarkan tekanan yang wujud di tempat kerja namun faktor tersebut tidak boleh menerangkan bullying secara tepat tanpa disertai sekali dengan Kepribadian korban (Fisher-Blando, J. L, 2008).

Adapun sumbangan kepribadian

muslim secara keseluruhan kepribadian muslim terhadap perilaku bullying setelah dilakukan analisis statistik, diperoleh $\mathrm{R}$ Square ,170. Jadi sumbangan kepribadian muslim keseluruhan terhadap perilaku bullying sebesar $17,0 \%$. Sedangkan sisanya sebesar $83 \%$ dipengaruhi oleh variabel lain selain variabel independent (kepribadian muslim) seperti, lingkungan sosial, iklim organisasi, kepemimpinan dan lain sebagainya.

\section{SIMPULAN}

Berdasarkan hasil analisis yang telah dilakukan, disimpulkan bahwa hipotesis diterima; ada pengaruh yang signifikan perilaku bullying terhadap kepribadian muslimpada perawat Rumah Sakit Palembang dengan hasil $\mathrm{r}^{2}$ sebesar $170, \mathrm{~F}=30,278, \mathrm{P}=$ ,000 $(<0,05)$. Hal ini menunjukkan bahwa hasil uji regresi dengan nilai Sig. 0,000 yang berarti nilai Sig. $<0,05$. Kepribadian muslim berkontribusi sebesar $17,0 \%$ terhadap perilaku bullying, sedangkan $83, \%$ dipengaruhi oleh variabel atau faktor lain yang tidak diikutsertakan dalam penelitian ini.Dengan demikian, semakin tinggi pemahaman dan aktualisasi kepribadian muslim dalam kehidupan sehari-hari maka, semakin rendah perilaku bullying.

\section{DAFTAR PUSTAKA}

Angela S. Book, Anthony A. Volk, Ashley Hosker. Adolescent bullying and personality: An adaptive, approach Department of child and youth studies,
Brock University, St. Cathrines, Ontario, Canada L2S 3A. Personality and individual Differences,52 (2012) 218-223

Balducci, C,. Cecchin, M,. Fraccaroli, F. \&Schaufeli, W. B. (2012). Exploring the Relasionship Between workaholism and workplase aggressive behaviour: The role of job-related emotion. Personaliti and individual defferences,

Coyne, I., Smith - Lee Chong, P., Randal, P. \& Seigne E. (2002). Subjective and objective measures of bullying and their impact on incident rates, individu differences and perceptions of team effectiveness. Proceedings of the international Conference on Bullying at Work.

Dahlena, E.R., Edwards, B.D, Turbe, T., Zyphurd, M.J., \& Warren, C.R. ( 2012) Talking a look Behind the wheel: An Investigation into the personality predictors of aggressive driving. Accident and Analysis Prevention, 4519

De Boer Tj. (1967),The History of Philosophy in Islam.New York: Dover Publication.

Davenport, N., Distler Schwartz, R., Elliot, (1999). G. Mobbing: Emotional Abuse in the American Workplace. Ames, Iowa: Civil Society Publishing.

Dewi, S. P. (2013).Hubungan Kejadian Bullying Verbal dengan Tingkat Stres Kerja Perawat di Ruang Rawat Inap RSUP M. Djamil Padang. Universitas Andalas.

Djurkovic, N., McCormack, D., \& Casimir, G. (2004). The Physical and Psychological Effects of Workplace Bullying and their Relationship to 202 Intention to Leave: A Test of the Psychosomatic and Disability Hypothesis. International Journal of Organization Theory and Behavior, 7(4), 469- 497.

Dye, Thomas R, . 2005. Understanding Public Policy, Eleventh Edition. New 
Jersey: Pearson Prentice Hall, 45.

E. Sismani Papacosta and others, "Bullying Phenomenon and Preventive Programs in Cyprus's School System" International Journal of Mental Health Promotion. Vol. 16. No. 1

Einarsen, S., Hoel, H., Notelaers, G. Measuring Exposure to Bullying and Harassment at Work: Validity, Factor Structure and Psychometric Properties of the Negative Acts QuestionnaireRevised. Journal of Work and Stress, 23(1), (2009), 24-44.

(2014), 67-80.

Einarsen, S., Raknes, B., Matthiesen, S. (1994). Bullying and Harassment at Work and their Relationships to Work Environment Quality: An Exploratory Study. European Work and Organizational Psychologist, 4(4), 381401.

Faiza, Salahsiah,\& Sharifuddin, (2015). Personaliti dari Perspektif al-Ghazali . Selangor: Universiti Kebangsaan Malaysia. 25-41.

Fisher-Blando, J. L. (2008).Workplace bullying:Aggressive behavior and its effect on job satisgfaction and productivity. University of Phoenix.

Frager, Robert. (2002). Heart, Self,\& Soul: The Sufi Psychology of Grouth, Balance and Harmony. Wheaton, USA : Theological Publ. House. Edisi terjemahanIndonesia oleh Hasymiyah Rauf. 2002. Psikologi Sufi untuk Transformasi: Hati diri, dan Jiwa. Jakarta: Serambi Ilmu Semesta.

Hadi, Sutrisno. (2000) Metodologi Research. Jilid 1, 2, dan 3 Yogyakarta: Andi Offset., 32.

Hoel, H. \& Cooper, C. , (2000), Destructive Conflict and Bullying at Work. Study Report. Manchester: University of Manchester Institute of Science and Technology25.

Kerlinger, F.N. (2004). Azas-azas Penelitian Behavior. Ahli Bahasa Landung, R.S. (Yogyakarta: BPFE-Gadjah Mada University Press.), 106.
Khalib, A.L. and Ngan, H.U. (2006). Workplace Bullying: Time to Understand its Roots. Malaysian Journal of Community Health. 1, 12.

Ma'an Zidadat. (1986). al-Mawsu'ât alFalsafiyah al-'Arabiyah (Arab: Inma' al-'Arabiy,

Martino, V. Di, Hoel, H. \& Cooper, c. (2003). Preventing Violence and Harassment in the Workplace.

Mikkelsen, E.G. \& Einarsen, S. (2001). Bullying in Danish Work-Life: Prevalence and Health Correlates.

European Journal of Work and Organizational Psychology, 10 (4).

Mujib,Abdul. (2007)Kepribadian dalam Psikologi Islam. Jakarta: PT RajaGrafindo Persada.

Muhammad Mahmûd Mahmûd. (1984). 'Ilm al-Nafs al-Ma'âshir fì Dhaw'i al-Islâm (Jeddah: Dâr al- Syurûq.

Najjar, Amir. (2001). Ilmu Jiwa dalam Tasawuf (Jakarta: Pustaka Azzam.

Nasution, Yasir. (1988). Manusia Menurut alGhazali. Jakarta: Rajawali Press.

Nasr, Sayyed Hossein. Sufism and the Integration of Man dalam C. malik (Ed.). (1972). God and Man in Contemporary Islamic Thought .Beirut: American University of Beirut, Contennial Publication.

Salin, D. .(2003).Ways of Explaining Workplace Bullying: A Review of Enabling, Motivating and Precipitating Structures and Processes in the Work Environment. Human Relations, 56(10), 1213-1232.

Sayyid Muhammad ibn Muhammad alHusaini al-Zubaidi. Ittihâf al-Sa'âdah al-Muttaqîn bi Syarh Ihyâ' 'Ulûm alDîn (Beirut: Dâr al-Kutub al-'Ilmiyyah, jilid VIII, 1989).

Suryabrata, Sumadi.(2009). Metodologi Penelitian(Jakarta: PT Raja Grafindo Persada,), 28.

Sheehan, M. \& Griffiths, J. 2011. Understanding the Context of Workplace Health Management As it Relates to Workplace Bullying. Internatonal Journal of Workplace Health Management, 4(1), 5-12. 
Syams al-Dîn ibn 'Abd Allâh Ibn Qayyim alJauziyyah. (1992).al-Rûh fi al-Kalâm 'alâ 'Arwâh al- 'Amwât wa al-'Ahwâ bi al-Dalîl min al-Kitâb wa al-Sunnah wa al-âtsâr wa al-Aqwâl al-'Ulamâ

(Beirut: Dâr al-Fikr, , 212-214.

Usman Najati. (2001). al-Qur'an dan Psikologi (Jakarta: Aras Pustaka.

Victor said Basil. Tt. Manhaj al-Bahts 'an alMa'rifah 'inda al-Ghazâlî (Beirut: Dâr al-Kitâb al-Libnâny).

Zapf, D., and Einarsen, S. (2001).Bullying in the WorkPlace: Recent Trends in Research and Practice- An Introduction. European Journal of Work and Organizational Psychology, 10 (4), 369-373. 